\title{
Regulation of serum leptin levels by gonadal function in rats
}

\author{
L Pinilla ${ }^{1}$, L M Seoane ${ }^{2}$, L Gonzalez ${ }^{1}$, E Carro ${ }^{2}$, E Aguilar ${ }^{1}$, F F Casanueva ${ }^{3}$ and C Dieguez ${ }^{2}$ \\ ${ }^{1}$ Department of Physiology, University of Cordoba, Cordoba, Spain, Departments of ${ }^{2}$ Physiology and ${ }^{3}$ Medicine, University of Santiago de Compostela, \\ Santiago de Compostela, Spain \\ (Correspondence should be addressed to C Dieguez, Facultad de Medicina, PO Box 563, 15700 Santiago de Compostela, Spain)
}

\begin{abstract}
The aim of this study was to investigate the regulation of serum leptin levels by gender and gonadal steroid milieu. Thus, we measured serum leptin levels by radioimmunoassay in (a) intact male and female rats, (b) female rats at different stages of the estrous cycle and (c) ovariectomized or orchidectomized rats. Gonadectomized groups were or were not implanted with silastic capsules (10 or $30 \mathrm{~mm}$ in length, $1.519 \mathrm{~mm}$ internal diameter; $3.06 \mathrm{~mm}$ external diameter) containing estradiol or testosterone and decapitated two weeks later.

We found (i) intact female rats weighing $50 \mathrm{~g}, 250 \mathrm{~g}$ and $300 \mathrm{~g}$ exhibited higher serum leptin concentrations than intact male rats of similar body weight; (ii) leptin concentrations were not affected by the phase of the estrous cycle; (iii) two weeks after gonadectomy serum leptin concentrations increased in both male (from $4.47 \pm 1.87$ to $8.76 \pm 1.24 \mathrm{ng} / \mathrm{ml}$ ) and female (from $1.97 \pm 0.46$ to $5.29 \pm 0.51 \mathrm{ng} / \mathrm{ml}$ ) rats. The ovariectomy-induced increase in serum leptin levels was not dependent, at least completely, on changes in body weight since it could be observed when comparisons were made between ovariectomized rats and intact rats in estrus matched for body weight. In contrast the effect of orchidectomy on serum leptin levels appears to be dependent on changes in body weight since it was no longer observed when comparisons were made with a group of intact male rats matched for body weight.

In conclusion, these results suggest that serum leptin concentrations are controlled by gonadal function either directly or as a consequence of changes in body weight.
\end{abstract}

European Journal of Endocrinology 140 468-473

\section{Introduction}

The $o b$ gene is an adipocyte-specific gene that encodes leptin, a protein that regulates food intake and energy expenditure. Recent data have clearly shown that the amount of leptin mRNA in adipocytes correlates with body weight. Furthermore, serum immunoreactive leptin levels show a strong positive correlation with body fat being elevated in obesity and decreased in states of severe malnutrition such as anorexia nervosa $(1-5)$

Recent data indicate that leptin may play an important role in the regulation of the hypothalamopituitary-gonadal axis. Exogenous leptin administration leads to an earlier vaginal opening in prepubertal mice (6) as well as advancing the onset of puberty in rats whose food intake is less than normal (7). Furthermore, leptin administration to ob/ob mice stimulates all aspects of their reproductive endocrine system and restores their fertility $(8,9)$. Whether these effects of leptin are exerted at central and/or peripheral levels is at present unclear $(10,11)$. However, data regarding the influence of gonadal hormones on the regulation of leptin secretion are more scarce. One of the most interesting findings in the field is the remarkable gender differences in circulating leptin levels in humans, leptin concentrations in women being nearly double those of men (3). These gender differences are present in humans even when subjects of opposite sex are compared after being carefully matched for the net amount of fat reserves, or at stages of development such as peri-puberty or birth when no differences in the amount of adipose tissue are present (12-19). In order to assess the regulation of serum leptin levels in the rat by gender and gonadal steroid milieu we studied the influence of (a) the sex, (b) the estrous cycle, and (c) gonadal function following gonadectomy and/or estrogen or testosterone replacement.

\section{Materials and methods}

\section{Animals and drugs}

Wistar rats born in our colony were used. The day on which animals were born was considered as day 1 of age. At this moment the litter size was adjusted to eight pups per dam. The animals were weaned at 21 days of age and housed in groups of 4-5 per cage. Animals were maintained under controlled conditions of temperature 


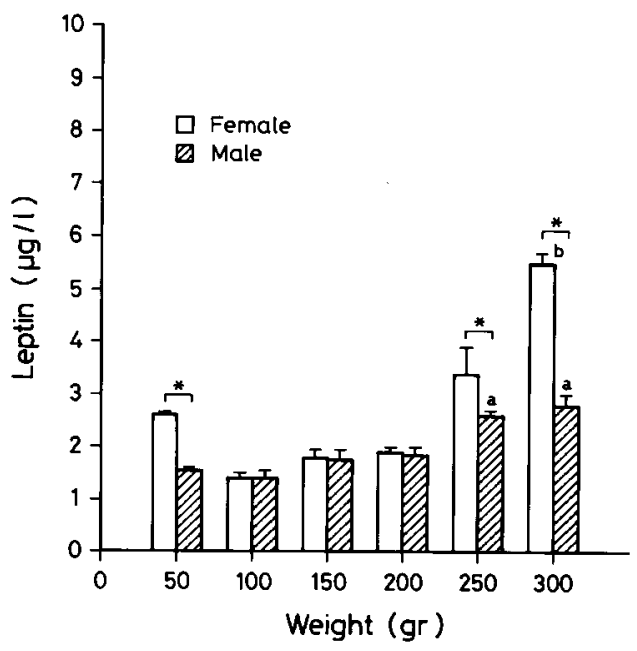

Figure 1 Influence of body weight on serum leptin concentrations (means \pm S.E.M.) in male and female rats. ${ }^{*} P<0.05$, ${ }^{a} P<0.05$ vs males weighing $50 \mathrm{~g},{ }^{\mathrm{b}} P<0.05$ vs females weighing $50 \mathrm{~g}$.

$\left(20^{\circ} \mathrm{C}\right)$ and light $(12 \mathrm{~h}$ light:12 h darkness) with free access to pelleted food (Panlab, Barcelona, Spain) and tap water. After vaginal opening, vaginal smear cycles were monitored daily. Only control females showing regular cycles were used.

Experimental designs In the first experiment, and in order to assess the influence of body weight on leptin secretion, rats $(n=6-8$ per group) were killed, independently of age, when they reached the appropriate body weight $(50,100,150,200,250$ and $300 \mathrm{~g})$. In a second group of experiments, both male and females rats ( $n=6-8$ per group) were killed at a defined age, on days 75 and 90, with females being in either the estrous or diestrous phase. In another experiment, adult male and female rats were gonadectomized or shamgonadectomized on day 60. Gonadectomized groups were or were not implanted with silastic capsules (10 or $30 \mathrm{~mm}$ in length, $1.519 \mathrm{~mm}$ internal diameter; $3.060 \mathrm{~mm}$ external diameter) containing estradiol or testosterone and decapitated two weeks later. Control females were killed in the diestrous or estrous phases of the cycle. All the experiments were carried out following the guidelines of the Helsinki declaration.

\section{Hormone measurements}

Blood samples were collected. After centrifugation, the serum was collected, frozen, and stored at $-20^{\circ} \mathrm{C}$ until assayed. Leptin was measured using a commercial kit (Linco, St Charles, MO, USA). The intra- and interassay coefficients of variation for concentrations of 1.6 and $11.6 \mathrm{ng} / \mathrm{ml}$ were $2.4 \%$ and $4.6 \%$ (intra) and $4.8 \%$ and $5.7 \%$ (inter) respectively. Testosterone and estradiol-17 $\beta$ were determined using commercial kits (Diagnostic Corporation, Los Angeles, CA, USA). Values are expressed as $\mathrm{ng} / \mathrm{ml}$ for testosterone and $\mathrm{pg} / \mathrm{ml}$ for estradiol- $17 \beta$. For each hormone, all samples were analyzed in the same assay, and the intra-assay coefficients of variation were $5 \%$ and $6 \%$ for testosterone and estradiol- $17 \beta$ respectively.

\section{Statistical evaluation}

Results are expressed as means \pm s.E.M. Data were evaluated for statistically significant differences by one- or two-way ANOVA followed by Tukey's test.

\section{Results}

\section{Influence of body weight, sex and phase of estrous cycle on leptin secretion}

Serum leptin levels in intact male rats were greater in rats weighing $250 \mathrm{~g}$ and $300 \mathrm{~g}$ than in rats weighing $50 \mathrm{~g}$ (Fig. 1). Intact female rats weighing $50 \mathrm{~g}, 250 \mathrm{~g}$ and $300 \mathrm{~g}$ exhibited higher serum leptin levels than intact male rats of similar body weight, but were no different at the other body weights studied (100 g, $150 \mathrm{~g}$ and $200 \mathrm{~g}$ ).

Serum leptin concentrations increased between day 75 and $90(\mathrm{~F}=22,13 ; P<0.001$, two-way ANOVA $)$ and were higher in males than in females. No significant differences were observed between females in the estrous or diestrous phases (Table 1).

\section{Effects of gonadectomy and steroid replacement on leptin secretion}

Table 2 shows the body weight and leptin concentrations in females and males 15 days after gonadectomy.

Table 1 Serum leptin concentrations and body weight in adult male and female rats. Values are given as means \pm S.E.M. $(n=10-20$ animals $)$.

\begin{tabular}{|c|c|c|c|c|}
\hline \multirow[b]{2}{*}{ Group } & \multicolumn{2}{|c|}{ Leptin (ng/ml) } & \multicolumn{2}{|c|}{ Body weight (g) } \\
\hline & 75 days & 90 days & 75 days & 90 days \\
\hline Males & $4.48 \pm 0.83$ & $8.36 \pm 1.08^{a}$ & $320 \pm 21$ & $376 \pm 16^{a}$ \\
\hline Females (diestrus) & $1.98 \pm 0.15^{\star *}$ & $3.84 \pm 0.61^{* *, a}$ & $252 \pm 4.6^{\star *}$ & $266 \pm 7.8^{* *}$ \\
\hline Females (estrus) & $1.97 \pm 0.18^{* *}$ & $3.08 \pm 0.52^{\star \star, a}$ & $248 \pm 4.2^{\star *}$ & $264 \pm 6.9^{\star *}$ \\
\hline
\end{tabular}

${ }^{\star *} P \leq 0.01$ vs males, ${ }^{a} P \leq 0.01$ vs 75 days (two-way ANOVA followed by Tukey's test). 
Table 2 Serum leptin concentrations and body weight in adult male and female rats ( 75 days-old) two weeks after gonadectomy. Values are given as means \pm S.E.M. $(n=10-20$ animals $)$.

\begin{tabular}{lccccc}
\hline & \multicolumn{2}{c}{ Leptin $(\mathrm{ng} / \mathrm{ml})$} & & \multicolumn{2}{c}{ Body weight $(\mathrm{g})$} \\
\cline { 2 - 3 } \cline { 5 - 6 } Group & Intact & Gonadectomized & & Intact & Gonadectomized \\
\hline Males & $4.47 \pm 1.87$ & & & $320 \pm 21$ & $366 \pm 26^{\mathrm{a}}$ \\
Females & $1.97 \pm 0.46^{* *}$ & $5.29 \pm 0.51^{* *, a}$ & & $252 \pm 5^{* *}$ & $267 \pm 17^{* *}$ \\
\hline
\end{tabular}

${ }^{* *} P \leq 0.01$ vs males, ${ }^{a} P \leq 0.01$ vs intact group (two-way ANOVA followed by Tukey's test).

Gonadectomy increased body weight significantly only in males, while the increase in serum leptin concentrations was significant in both sexes.

The effects of estradiol and testosterone replacement in ovariectomized females is shown in Table 3. Ovariectomy significantly decreased the serum concentrations of testosterone and estradiol and increased those of leptin (Table 3). The ovariectomy-induced increase in serum leptin levels was not dependent, at least completely, on changes in body weight since it could be observed when comparisons were made between ovariectomized rats and intact rats in estrous matched for body weight (Fig. 2).

Implantation of silastic capsules containing testosterone significantly increased serum testosterone levels and returned leptin concentrations to values similar to those measured in intact females. The inhibitory effect of testosterone on serum leptin levels was observed despite the fact that testosterone administration $(3 \mathrm{~cm}$ silastic capsule) led to a marked increase in body weight (Table 3). Implantation of silastic capsules containing estradiol significantly increased serum estradiol levels, decreased body weight, but did not affect leptin concentrations which were similar to those in ovariectomized females. Next, and in order to unmask the possibility that the lack of effect of estrogen administration could be due to a decrease in body weight, we compared estrogen-treated rats with intact female rats matched for body weight. Serum leptin levels in ovariectomized rats implanted with $1 \mathrm{~cm}$ silastic capsules of estradiol were not significantly different from intact female rats matched for body weight $(224 \pm$ $16 \mathrm{~g}$ ). However, rats implanted with a $3 \mathrm{~cm}$ silastic capsule of estradiol showed much greater serum leptin levels than the appropriate group of intact female rats matched for body weight (Fig. 2).

In male rats, orchidectomy significantly decreased testosterone and estradiol concentrations, while body weight and leptin levels increased (Table 4). In order to rule out the possibility that the changes in serum leptin levels could be due to changes in body weight, we compared gonadectomized rats with intact rats matched for body weight. Serum leptin levels were similar in orchidectomized rats and in intact rats matched for body weight (Fig. 3). Implantation of silastic capsules containing testosterone significantly increased the serum testosterone levels, but the values achieved were significantly lower than in intact males. Serum leptin concentrations were similar in orchidectomized males treated or not with testosterone. The lack of effect of testosterone on serum leptin levels could not be accounted for by a change in body weight (Table 4). Implantation of silastic capsules containing estradiol increased the serum estradiol levels several fold higher than those measured in intact males. In contrast with data obtained in females, the higher dose of estradiol decreased leptin concentrations which returned to values similar to those measured in intact males. However, body weight increased after orchidectomy and decreased significantly in groups treated with estradiol (Table 4). Therefore, further comparisons were carried out with intact male rats matched for

Table 3 Testosterone $(T)$, estradiol $\left(E_{2}\right)$, and leptin concentrations in intact, ovariectomized (ovx) and ovariectomized + steroid-treated female rats. The animals were ovariectomized on day 60 , implanted with silastic capsules $(1$ or $3 \mathrm{~cm}$ ) containing testosterone or estradiol and decapitated on day 75 . Values are given as means \pm S.E.M. $(n=10-20$ animals $)$.

\begin{tabular}{|c|c|c|c|c|}
\hline Group & $\mathbf{T}(\mathrm{ng} / \mathrm{ml})$ & $E_{2}(p g / m l)$ & Body weight (g) & Leptin (ng/ml) \\
\hline Intact & $0.05 \pm 0.01$ & $78 \pm 4.7$ & $252 \pm 18$ & $3.18 \pm 0.93$ \\
\hline Ovx & ND & $33 \pm 2.8^{* *}$ & $267 \pm 17$ & $5.29 \pm 0.51^{\text {** }}$ \\
\hline $\mathrm{Ovx}+\mathrm{T}(1 \mathrm{~cm})$ & $1.10 \pm 0.20^{* * a}$ & $62 \pm 6.1$ & $273 \pm 22$ & $3.54 \pm 0.43^{\mathrm{a}}$ \\
\hline Ovx + T (3cm) & $2.45 \pm 0.27^{\star *, a}$ & $63 \pm 5.7$ & $292 \pm 18^{\star *, a}$ & $3.39 \pm 0.92^{\mathrm{a}}$ \\
\hline$O v x+E_{2}(1 \mathrm{~cm})$ & - & $190 \pm 6^{\star \star, a}$ & $224 \pm 16^{\star \star, a}$ & $5.26 \pm 0.61^{* *}$ \\
\hline $\mathrm{Ovx}+\mathrm{E}_{2}(3 \mathrm{~cm})$ & ND & $443 \pm 41^{\star *, a}$ & $210 \pm 14^{* \star, a}$ & $5.44 \pm 0.98^{* *}$ \\
\hline
\end{tabular}

$\mathrm{ND}$, not detected.

${ }^{\star *} P \leq 0.01$ vs respective intact group, ${ }^{a} P \leq 0.01$ vs ovariectomized group (ANOVA followed by Tukey's test). 
Figure 2 Influence of estrogen administration $\left(E_{2}\right)$ (silastic capsules of either $1 \mathrm{~cm}$ or $3 \mathrm{~cm}$ ) and/or ovariectomy (OVX) on serum leptin concentrations (means \pm S.E.M.) in female rats. ${ }^{*} P<0.05$,

${ }^{\star \star} P<0.01$. In each case comparisons were carried out with a group of control rats matched for body weight.
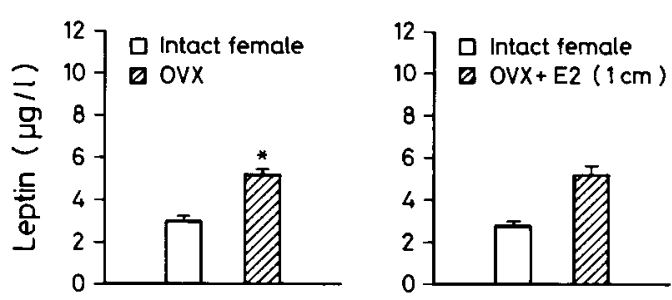

body weight. Serum leptin levels in orchidectomized rats treated with estradiol ( $3 \mathrm{~cm}$ silastic capsule) were not significantly different from those recorded in a group of intact male rats matched for body weight (Fig. 3). In contrast, implantation of a $1 \mathrm{~cm}$ silastic capsule of estradiol in orchidectomized rats led to a marked increase in serum leptin levels compared with a group of intact male rats matched for body weight (Fig. 3).

\section{Discussion}

Gonadal steroids affect energy balance and adiposity in a variety of mammalian species, via multiple redundant mechanisms. These include regulation of food intake at the central level, modulation of enzyme activity at the tissue level - transferring stored lipids between white adipose tissue storage depots to other tissues where they may be oxidized, and regulation of energy expenditure (20).

Indirect evidence obtained in human subjects suggests that some of the effects of gonadal steroids on food intake and body weight can be mediated to some extent by influencing serum leptin levels and hypothalamic leptin receptor gene expression. Thus, after adjusting for fat mass, females have higher leptin levels than males. However, the reasons of this sexual dimorphism are at present unclear. It could be due to a stimulatory effect of estrogen and progesterone on leptin secretion, or alternatively, to an inhibitory effect of androgens on leptin. It could also be due to differences in fat distribution between male and females since subcutaneous fat produces more leptin mRNA than intra-abdominal fat. Finally, female adipose tissue may be more sensitive to hormones that stimulate leptin production, such as insulin or glucocorticoids (12-19).

In this work we assessed the role of gonadal hormones on serum leptin levels in rats. Our data, without taking into account changes in body weight, indicate that serum leptin levels (a) were not affected by the estrous phase, (b) increased significantly two weeks after ovariectomy or orchidectomy, (c) decreased in ovariectomized female rats after testosterone treatment and in orchidectomized males after estradiol administration. However, the fact that in both intact male and female rats leptin levels are increased - though not in a linear fashion - in relation to body weight raises the possibility that some of the effects of gonadal hormones on serum leptin levels could be a consequence of changes in body weight. Therefore, further analysis of the data was carried out after carefully matching the different experimental groups for body weight. When body weight was taken into account our data showed that serum leptin levels (a) were greater in young female rats, $50 \mathrm{~g}$ body weight, and adult female rats, $250 \mathrm{~g}$ and $300 \mathrm{~g}$ body weight, than in intact male rats of similar body weight, (b) were not influenced by the estrous cycle, (c) were greater in ovariectomized than in intact female rats. Somewhat unexpectedly estrogen administration to ovariectomized rats, although only at high doses, increased even further leptin levels in ovariectomized rats. On the other hand, testosterone administration inhibited the increase in leptin levels induced by ovariectomy. Finally it was shown that serum leptin levels were not affected by orchidectomy in male rats.

Table 4 Testosterone $(T)$, estradiol $\left(E_{2}\right)$ and leptin concentrations in intact, orchidectomized (Orch) and orchidectomized + steroid-treated male rats. The animals were orchidectomized on day 60 , implanted with silastic capsules (1 or $3 \mathrm{~m}$ ) containing testosterone or estradiol and decapitated on day 75 . Values are given as means \pm S.E.M. $(n=10-20$ animals $)$.

\begin{tabular}{|c|c|c|c|c|}
\hline Group & $\mathbf{T}(\mathrm{ng} / \mathrm{ml})$ & $\mathbf{E}_{2}(\mathrm{pg} / \mathrm{ml})$ & Body weight $(\mathrm{g})$ & Leptin (ng/ml) \\
\hline Intact & $7.08 \pm 1.53$ & $67 \pm 4.5$ & $320 \pm 21$ & $3.58 \pm 0.45$ \\
\hline Orch & ND & $34 \pm 6.0^{\star *}$ & $366 \pm 17^{*}$ & $7.84 \pm 2.14^{\star *}$ \\
\hline Orch + T $(1 \mathrm{~cm})$ & $0.46 \pm 0.04^{* *, a}$ & $56 \pm 9.1$ & $361 \pm 10^{*}$ & $5.25 \pm 0.63$ \\
\hline Orch + T $(3 \mathrm{~cm})$ & $1.38 \pm 0.27^{\star \star, a}$ & $57 \pm 6.6$ & $352 \pm 12^{*, a}$ & $9.25 \pm 0.82^{* *}$ \\
\hline Orch $+E_{2}(1 \mathrm{~cm})$ & ND & $126 \pm 6^{\star *, a}$ & $300 \pm 10^{*, a}$ & $7.56 \pm 0.53^{\star}$ \\
\hline Orch $+E_{2}(3 \mathrm{~cm})$ & ND & $345 \pm 53^{\star *, a}$ & $250 \pm 7^{\star *, a}$ & $3.79 \pm 0.43^{a}$ \\
\hline
\end{tabular}

ND, not detected.

${ }^{*} P \leq 0.05,{ }^{* *} P \leq 0.01$ vs respective intact group, ${ }^{a} P \leq 0.01$ vs orchidectomized group (ANOVA followed by Tukey's test). 

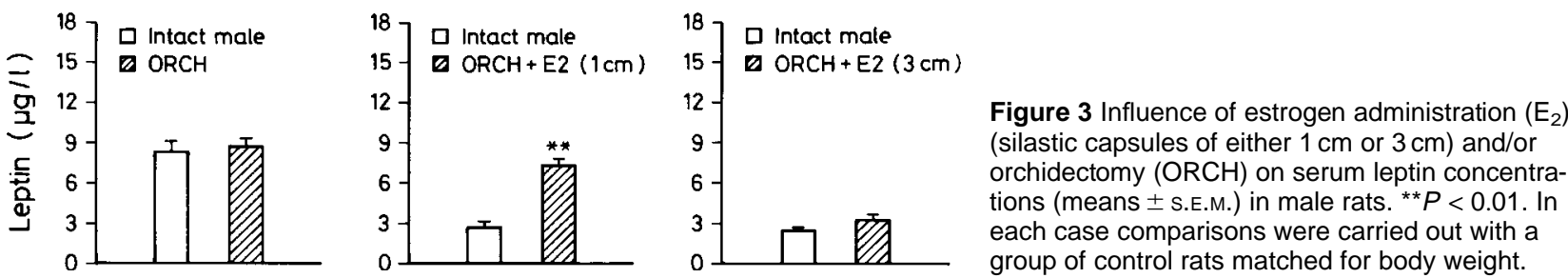

Taken together our data suggest that gonadal steroids can influence serum leptin levels through at least two different mechanisms. One is consequent to changes in body weight. However, some of the changes observed in serum leptin levels after modification of the sex steroid milieu cannot be explained by changes in body weight, suggesting the existence of some other mechanism of action. The changes in body weight probably reflect changes in fat stores since we have found a similar relationship between serum leptin levels and either body weight or fat content in normal rats (F Casanueva and $\mathrm{X}$ Casabiell, unpublished data). In support of the second possibility, a stimulatory role of estrogens on leptin secretion has been proposed, since addition of estradiol to isolated adipocytes increased ob mRNA expression in vitro $(21,22)$. Also, Shimizu et al. (23) showed that leptin concentrations decreased in female rats 8 weeks after ovariectomy and recovered after implantation of silastic capsules containing estradiol. However, the serum estradiol concentrations in female rats were not measured in this study. The possibility that changes in leptin concentrations after ovariectomy were dependent on changes in body weight should be considered, since body weight increased significantly 8 weeks after ovariectomy, but not at shorter periods (23 and present results). Alternatively, it is possible that estrogen administration overcomes the lower leptin levels associated with decreased body weight in normal rats.

It has been proposed that androgens inhibit leptin secretion because leptin concentrations are higher in premenopausal females than in males (24) and the increase in testosterone levels in children are associated with decreased serum leptin concentrations (13). Our data show that in the adult male rat the effects of testosterone are mediated by changes in body weight, and therefore do not support a direct inhibitory effect of testosterone on leptin secretion, as suggested by some data obtained in hypogonadal human subjects (25). Nevertheless, these data are in agreement with those obtained in normal adult human subjects where it has been found that short-term exogenous testosterone administration does not modify leptin levels (V Popovic, D Micic, C Dieguez \& F Casanueva, unpublished observations). Finally, the effects of testosterone - when comparisons were carried out taking into account changes in body weight - appear to be sexually dimorphic, since testosterone administration to ovariectomized, but not to orchidectomized, rats led to a decrease in serum leptin levels. Further studies are needed in order to clarify the mechanisms of this different response.

In conclusion, our results showed that serum leptin concentrations in the rat are dependent on gonadal function. Gonadal hormones regulate leptin levels either directly or as a consequence of changes in body weight. This dual action of gonadal hormones should be considered for further studies on the mechanisms of the control and physiology of leptin.

\section{Acknowledgements}

This work was supported by grants from the Fondo de Investigaciones Sanitarias, Spanish Ministry of Health and the Xunta de Galicia.

\section{References}

1 Zhang Y, Proenca R, Maffei M, Barone M, Leopolod L \& Friedman J. Positional cloning of the mouse obese gene and its human homologue. Nature 1994372 425-432.

2 Campfie1d LA, Smith FJ, Guisez Y, Devos R \& Burn P. Recombinant mouse OB protein: evidence for a peripheral signal linking adiposity and central neural networks. Science $1995269546-549$.

3 Meier CA. Leptin secretion and action: an update. European Journal of Endocrinology 1996134 543-544.

4 Ferron F, Considine RV, Peino R, Lado IG, Dieguez C \& Casanueva FF. Serum leptin concentrations in patients with anorexia nervosa, bullimia nervosa and non-specific eating disorders correlate with the body mass index but are independent of the respective disease. Clinical Endocrinology 199746 289-293.

5 Grinsponn S, Gulick T, Askari H, Landt M, Lee K, Anderson E et al. Serum leptin levels in women with anorexia nervosa. Journal of Clinical Endocrinology and Metabolism 199681 3861-3863.

6 Chehab FF, Mounzih K, Lu R \& Lim ME. Early onset of reproductive function in normal female mice treated with leptin. Science 1997275 889-891.

7 Cheung CC, Thornton JE, Kuijper JL, Weigle DS, Clifton DK \& Steiner RA. Leptin is a metabolic gate for the onset of puberty in the female rat. Endocrinology 1997138 855-858.

8 Barash IA, Cheung CC, Weigle DS, Ren H, Kabigting EB, Kuijper JL et al. Leptin is a metabolic signal to the reproductive system. Endocrinology $19961373144-3147$.

9 Chehab FF, Lim ME \& Lu R. Correction of the sterility defect in homozygous obese female mice by treatment with the human recombinant leptin. Nature Genetics 199612 318-320.

10 Carro E, Pinilla L, Seoane ML, Considine RV, Aguilar E, Casanueva FF et al. Influence of endogenous leptin tone on oestrous cycle and LH pulsatility in female rats. Neuroendocrinology 199766 375377.

11 Zachow RJ \& Magoffin DA. Direct intraovarian effects of leptin: impairment of the synergistic action of insulin-like growth factor-I on follicle-stimulating hormone-dependent estradiol-17 $\beta$ 
production by rat ovarian granulosa cells. Endocrinology 1997 138 847-850.

12 Rosenbaum M, Nicolson M, Hirsch J, Heymsfield SB, Gallagher D, Chu $\mathrm{F}$ et al. Effects of gender, body composition, and menopause on plasma concentrations of leptin. Journal of Clinical Endocrinology and Metabolism 199681 3424-3427.

13 Garcia Mayor RV, Andrade A, Rios M, Lage M, Dieguez C \& Casanueva FF. Serum leptin levels in normal children: relationship to age, gender, body mass index, pituitary-gonadal hormones, and pubertal stage. Journal of Clinical Endocrinology and Metabolism 199782 2849-2855.

14 Tome MA, Lage M, Camiña JP, Garcia-Mayor R, Dieguez C \& Casanueva FF. Gender-based differences in serum leptin levels from umbilical cord blood at delivery. European Journal of Endocrinology 1997137 655-658.

15 Schubring C, Kiess W, Englaro P, Rascher W, Dotsch J, Hanitsch S et al. Levels of leptin in maternal serum, amniotic fluid, and arterial and venous cord blood: relation to neonatal and placental weight. Journal of Clinical Endocrinology and Metabolism 199782 1480-1483.

16 Matsuda J, Ypkota I, Iida M, Murakami T, Naito E, Ito M et al. Serum leptin concentrations in cord blood: relationship to birth weight and gender. Journal of Clinical Endocrinology and Metabolism $1997821642-1644$

17 Montague CT, Prins JB, Sanders L, Digby JE \& O’Rahilly S. Depot and sex-specific differences in human leptin mRNA expression: implications for the control of regional fat distribution. Diabetes $199746342-347$.

18 Pombo M, Herrera E, Considine RV, Hermida RC, Galvez MJ, Martin T et al. Nocturnal rise of leptin in normal prepubertal and pubertal children and in patients with perinatal stalk-transection syndrome. Journal of Clinical Endocrinology and Metabolism 1997 82 2751-2754.

19 Clayton PE, Gill MS, Hall CM, Tillmann U, Whatmore AJ \& Price A. Serum leptin through childhood and adolescence. Clinical Endocrinology 199746 727-733.

20 Wade GN, Gray JM \& Bartness TJ. Gonadal influences of adiposity. International Journal of Obesity 1985 9 83-92.

21 Murakami T, Iida M \& Shimu K. Dexamethasone regulates obese expression in isolated rat adipocytes. Biochemical and Biophysical Research Conmunications 1995214 1260-1267.

22 Casabiell X, Piñeiro V, Peino R, Lage M, Camiña J, Gallego R et al. Gender differences in both spontaneous and stimulated leptin secretion by human omental adipose tissue in vitro: dexamethasone and estradiol stimulate leptin release in women but not in men samples. Journal of Clinical Endocrinology and Metabolism $1998832149-2155$.

23 Shimizu H, Shimomura Y, Nakanishi Y, Futawari T, Ohtani K \& Sato N. Estrogen increases in vivo leptin production in rats and human subjects. Journal of Endocrinology 1997154 285292.

24 Lonnquist F, Arner P, Nodfrords L \& Schalling M. Overexpression of the obese $(\mathrm{ob})$ gene in adipose tissue of human obese subjects. Nature Medicine 19951 950-953.

25 Jockenhovel F, Blum WF, Vogel E, Englaro P, Muller D, Reinwein D et al. Testosterone substitution normalizes elevated serum leptin levels in hypogonadal men. Journal of Clinical Endocrinology and Metabolism 199782 2510-2513.

Received 14 August 1998

Accepted 2 December 1998 